\title{
Formulation of Ceramic Water Filter Composition for the Treatment of Heavy Metals and Correction of Physiochemical Parameters in Household Water
}

\author{
Babafemi Ayodele Ajayi, Yinusa Daniel Lamidi* \\ Department of Glass and Ceramic Technology, Federal Polytechnic, Ado-Ekiti, Nigeria \\ Email: *lamdan2004@yahoo.com
}

Received 4 August 2015; accepted 13 November 2015; published 16 November 2015

Copyright (C) 2015 by authors and Scientific Research Publishing Inc.

This work is licensed under the Creative Commons Attribution International License (CC BY).

http://creativecommons.org/licenses/by/4.0/

(c) (i) Open Access

\begin{abstract}
The process of using ceramic water filter to remove contaminants and microbes in water processing is becoming more effective and popular among ceramists and homes in developing countries. However, ceramic filters are not known to treat heavy metals effectively. Therefore, this research work is targeted at developing ceramic water filter that is capable of removing heavy metals in water at household levels. The body composition is formulated with charcoal, saw dust, snail shell, glass cullet and clay so as to make it porous, remove microbes and treat heavy metals by adsorption process in the filter. The formulated bodies are shaped and fired to a temperature of $\left(850^{\circ} \mathrm{C}-900^{\circ} \mathrm{C}\right)$ and water is allowed to run through the material. Physiochemical and heavy metal test are conducted on the water and it is discovered that samples $G$ and $H$ have the highest flow rate and sample $H$ is effective for the treatment of microbe and the removal of heavy metals in water with significant reduction in Zinc, Nickel, Manganese, Lead, Chromium and Copper. It also shows that the filter which is produced is effective for high correction of physiochemical parameters in household water treatment.
\end{abstract}

\section{Keywords}

Ceramic Water Filter, Charcoal, Snail Shell and Cullet, Microbes, Physiochemical Test and Heavy Metals

\footnotetext{
*Corresponding author.
}

How to cite this paper: Ajayi, B. A., \& Lamidi, Y. D. (2015). Formulation of Ceramic Water Filter Composition for the Treatment of Heavy Metals and Correction of Physiochemical Parameters in Household Water. Art and Design Review, 3, 94-100. http://dx.doi.org/10.4236/adr.2015.34013 


\section{Introduction}

Water is said to be clean not only when it is colourless, odourless and tasteless but it should be free of microbes and heavy metals. Generally only $60 \%$ of the country's population has access to clean and safe water for domestic use (WHO/UNICEF, 2010). The most deadly diseases being contacted from water are always from microbial particles or presence of heavy metals that may be present in water through leaching or other processes. Most of the water resources in the countryside are contaminated with dissolved minerals and pathogenic organisms which can be highly infectious and disease-causing (Kosek et al., 2003). Several water filtration technologies have been started by educational initiatives and non-governmental organizations recently to resolve portable water scarcity (Sobsey et al., 2008), but this has not totally reduced it.

It was estimated that in 2010, 1.8 billion people consumed water being deemed "unsafe," and 783 million regularly used water sources unprotected from contamination (Bolton, 2009). Children are the most affected by ingestion of contaminated water: $15 \%$ of deaths in children under five years old are associated with the nearly 2.5 billion cases of diarrhea each year (ASM, 1990). This means that every year, 3.4 million children die as a direct result of diarrhea and other diseases caused by water-borne microbes, making it the second leading cause of death of children, especially in low- and middle-income countries (Onda et al., 2012).

It is therefore important to produce water filters for homes and most especially rural areas in other to reduce the risk of water borne diseases that can be contacted not only from dirty water but also from the presence of heavy metals in water. A filter is defined as a device, instrument or material, which removes impurities from whatever that passes through it. Therefore, ceramic water filtration as defined by (Brown et al., 2007) is the process that makes use of a porous ceramic (fired clay) medium to filter microbes or other contaminants from water. The pore size of the ceramic medium is sometimes small enough to trap anything bigger than a water molecule. From the ancient times to the present, water filters have evolved out of necessity, first to remove materials that affect appearance, then to improve bad tastes and further to remove contaminants that can cause disease and illness (Water Exchange, 2012).

Ceramic water filters were manufactured with locally available clay and sawdust. These filters were low cost but considered as efficient and sustainable technology to treat drinking water in developing countries (Sobsey et al., 2008). Most of the available ceramic water filters are not produced to treat heavy metals in water, hence, the aim of this research work is to investigate the possibility of producing ceramic water filter composition to treat heavy metals in water and correct physiochemical parameters in home use water. A calcium silicate composite is incorporated into the ceramic water filter to act like a tobermorite to trap and absorb heavy metal in its pores by metal ion capacity.

Tobermorite is a silicate hydrate mineral with chemical formular $\left(\mathrm{Ca}_{5} \mathrm{Si}_{6} \mathrm{O}_{16}(\mathrm{OH})_{2} \cdot 4 \mathrm{H}_{2} \mathrm{O}\right)$. It occurs in cement paste and can be found in nature as alteration mineral in metamorphosed limestone (Coleman, 2011). It works on the principle of absorbing and trapping of heavy metals in its pores and has metal ion adsorption capacity (handbook of mineralogy, 1954). The ratio of composition of $50 \%$ glass cullet $\left(\mathrm{SiO}_{2}\right)$ source and $50 \%$ snail shell (Calcium Silicate) source is very good for heavy metal treatment in water (Ajayi, 2013). This is introduced into the varying ratio of charcoal, sawdust and ball clay composition to act as tobermorite in the composition in other to treat heavy metal by adsorption process, correct physiochemical parameters and also act as a water filter for home use.

\section{Materials and Method}

The basic raw material used to make the ceramic water filters include ball clay minerals, snail shell, cullet, charcoal and sawdust from wood. The ball-clay mineral was preferred because it exhibits high plasticity to hold the filter particles together and it has a greater dry mechanical strength when fired (Prajapati, 2002).

The hardwood sawdust was preferred to softwood sawdust because it does not cause bloating and results in a more uniform pore formation with fewer defects in the filter (Katherine et al., 2000). The $50 \%$ snail shell and the $50 \%$ glass cullet composition were used so as to trap heavy metal in the composition by adsorption process (Ajayi et al., 2015).

\subsection{Materials and Equipment}

The material and equipment used for the research are: 


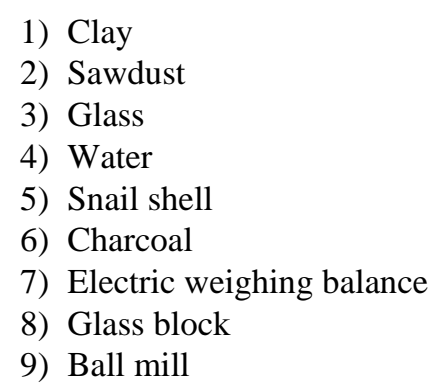

Clay. The clay was dug from Ikere-Ekiti, the clay was grinded to a fine particle, then the clay was soaked in a soaking pit and mixed together until it forms slip. The clay slip was later transfer into the dryer pit to remove excess water present in the clay mixture in order to get plastic materials. The plastic clay was allowed to dry for three weeks and was grinded using the grinding machine to have powder clay. Clay forms the base material of the water filter element. Clay can be readily accessed in most locations worldwide, it can be mould easily, and when fired in the kiln it changes chemically to become a strong porous container that does not deteriorate in water. A normal clay pot allows an extremely slow movement of water through pores that exist between the platelets of fired clay. The size of these pores have been measured (by an electron microscope) to be in the range of 0.6 to 3.0 microns $(\mu \mathrm{m})$ which are capable of straining out most bacteria, protozoa, and helminths (Lantagne, 2001), as well as dust, and organic matter.

Sawdust. The sawdust was gotten from a sawmill and furniture workshop in Ado-Ekiti. The saw dust was sieved in other to have a fine particles size. This will allow for easy mixing of the saw dust with the other materials.

Water. The water was gotten from the borehole. The water was use to mix the clay, snail shell, glass and charcoal in the sawdust to form a semi plastic workable material.

Snailshell. The snail shell was gotten around Federal Polytechnic Ado-Ekiti environment. It was calcined at a temperature of $800^{\circ} \mathrm{C}$ and pulverised to powder using the ball mill machine. The powder was taken to the laboratory for analysis to determine the percentage of calcium present in the shell.

Charcoal. Charcoal was gotten at a settlement near Federal Polytechnic Ado-Ekiti area (Aba Erinfun). It was sun dries for some days and milled to powder using the ball mill machine.

Cullet. The cullet was gotten from waste wine bottles within the environment. The cullet was poured inside a ball milling and milled to form a slip. The slip was sundried to form dried cake which was later crushed to powder using the grinding machine.

\subsection{Effect of Calcining the Snail Shell}

Calcination is the process of heating of raw materials or mixture to the temperature necessary to drive off the chemically combined water, carbon dioxide and other volatile materials present in it. The process of grinding is made easy when materials are calcined.

\section{Procedure}

The raw materials were weighed and combined in various ratios with some percentage of water to produce a homogenous plastic body. This is well kneaded to remove any available pores in the clay and was used to form a circular shape body. The shape of the produced body was measured to have a diameter of 2.5 inches and a height of 0.5 inches. The various samples were allowed to dry for 4 weeks to remove any free water in the sample and then fired in an electric kiln to a temperature of $850^{\circ} \mathrm{C}$. Flowing water was gotten from a stream in Isan-Ekiti, Ekiti State, Nigeria and was taken to the laboratory for analysis. The water was allowed to pass through the sample composed and the flow rate of the water samples was taken. The filtered water was then taken to the laboratory to test the effect of the water filter composition.

\section{Mechanism of Filtration}

The density and size of a filter's pores are two of the factors that affect filter performance (Hagan et al., 2009). The sawdust which is mixed with the clay burn out during firing and this makes the filter porous thereby allow- 
ing water to pass through it. Microbes and particles which are larger in size than the pores in the filter membrane are blocked from flowing through the outermost membrane layer thereby making the water free of dirt and microbes while the heavy metal is trapped within the filter by adsorption process.

\section{Results and Discussion}

Table 1 and Table 2 show the result of the various composition of the sample filters produced both in ratios and in mass(gram) respectively.

Table 3 shows the result of the characterization of the calcined snail shell so as to know the percentage of calcium present in the sample.

Table 4 shows the result of the physiochemical analysis of the raw sample in other to determine the effect of the water filter after filtration.

From Table 5, samples produced $\mathrm{G}$ and $\mathrm{H}$ have high flow rate of $1.282 \mathrm{ml} / \mathrm{min}$ and $1.562 \mathrm{ml} / \mathrm{min}$, hence it can be used effectively for household water treatment while the remaining samples have a lower flow rate.

Table 6 shows the AAS result of the raw water sample in order to know the percentage of heavy metal present in the sample. This is important so as to know the effectiveness after filtration.

The result of Table 7 reveals that the samples $\mathrm{G}$ and $\mathrm{H}$ are good compositions for the effective treatment of the physiochemical parameters in water.

Table 8 and Table 9 give the results of the treated samples; this is to know effect of the water filter composition on the water. From Table 9 it showed that sample $\mathrm{H}$ is more effective than sample $\mathrm{G}$ for the treatment of heavy metals in water.

Table 1. Composition of bodies in percentages (\%).

\begin{tabular}{cccccccc}
\hline S/N & SAWDUST\% & CHARCOAL $\%$ & $\begin{array}{c}\text { SNAIL } \\
\text { SHELL\% }\end{array}$ & GLASS\% & CLAY\% & 100\% & $\begin{array}{c}\text { VOL } \\
\text { WATER (ml) }\end{array}$ \\
\hline A & 4 & 16 & 10 & 10 & 60 & 100 & 200 \\
B & 5 & 5 & 5 & 5 & 80 & 100 & 200 \\
C & 0 & 10 & 0 & 0 & 90 & 100 & 200 \\
D & 10 & 0 & 0 & 0 & 90 & 100 & 200 \\
E & 0 & 0 & 5 & 5 & 90 & 100 & 200 \\
F & 0 & 0 & 10 & 10 & 80 & 100 & 200 \\
G & 10 & 0 & 15 & 15 & 60 & 100 & 200 \\
H & 10 & 10 & 20 & 20 & 40 & 100 & 200 \\
I & 5 & 5 & 10 & 10 & 70 & 100 & 200 \\
\hline
\end{tabular}

Source: authors field work (2015).

Table 2. Composition of bodies in grams (g).

\begin{tabular}{cccccccc}
\hline S/N & Sawdust (g) & Charcoal (g) & Snailshell (g) & Glass (g) & Clay (g) & 500 g & Vol. of Water (ml) \\
\hline A & 20 & 80 & 50 & 50 & 300 & 500 & 200 \\
B & 25 & 25 & 25 & 25 & 400 & 500 & 200 \\
C & 0 & 50 & 0 & 0 & 450 & 500 & 200 \\
D & 50 & 0 & 0 & 0 & 450 & 500 & 200 \\
E & 0 & 0 & 25 & 25 & 450 & 500 & 200 \\
F & 0 & 0 & 50 & 50 & 400 & 500 & 200 \\
G & 50 & 0 & 75 & 75 & 300 & 500 & 200 \\
H & 50 & 50 & 100 & 100 & 200 & 500 & 200 \\
I & 25 & 25 & 50 & 50 & 350 & 500 & 200 \\
\hline
\end{tabular}

Source: authors field work 2015. 
Table 3. XRF analysis result of snail shell ash.

\begin{tabular}{cccccccccc}
\hline ELEMENT & $\mathrm{Ca} \%$ & $\mathrm{Mg} \%$ & $\begin{array}{c}\mathrm{Fe} \\
(\mathrm{ppm})\end{array}$ & $\begin{array}{c}\mathrm{Ni} \\
(\mathrm{ppm})\end{array}$ & $\begin{array}{c}\mathrm{Mn} \\
(\mathrm{ppm})\end{array}$ & $\begin{array}{c}\mathrm{Zn} \\
(\mathrm{ppm})\end{array}$ & $\begin{array}{c}\mathrm{Cr} \\
(\mathrm{ppm})\end{array}$ & $\begin{array}{c}\mathrm{Cu} \\
(\mathrm{ppm})\end{array}$ & $\begin{array}{c}\mathrm{Se} \\
(\mathrm{ppm})\end{array}$ \\
\hline Conc Value & 92.41 & 3.35 & 248.50 & 1.30 & 4.22 & 10.80 & 8.10 & 5.90 & 0.57 \\
\hline
\end{tabular}

Table 4. Physiochemical analysis of untreated water sample.

\begin{tabular}{cc}
\hline Physiochemical Parameters & Untreated Sample \\
\hline Total dissolve solid & $106 \mathrm{mg} / \mathrm{L}$ \\
Conductivity & $54 \mathrm{Ns} / \mathrm{cm}$ \\
PH & 8.4 \\
Hardness & $12.4 \mathrm{mg} / \mathrm{L}$ \\
Iron & $5.2 \mathrm{mg} / \mathrm{L}$ \\
Alkalphate & $10.2 \mathrm{mg} / \mathrm{L}$ \\
Turbidity & $150 \mathrm{mg} / \mathrm{L}$ \\
Chloride & $16.9 \mathrm{NTU}$ \\
Nitrate & $20.2 \mathrm{mg} / \mathrm{L}$ \\
Colour & $14.0 \mathrm{mg} / \mathrm{L}$ \\
Odour & Slightly coloured \\
Taste & Objectionable \\
\hline
\end{tabular}

Table 5. Flow rate of filtered samples.

\begin{tabular}{cccccccccc}
\hline Samples & A & B & C & D & E & F & G & H & I \\
\hline Millilitres & 100 & 100 & 100 & 100 & 100 & 100 & 100 & 100 & 100 \\
Minutes & 105 & 118 & 150 & 150 & 170 & 179 & 78 & 64 & 120 \\
$\begin{array}{c}\text { Flow rate } \\
\text { ml/mins }\end{array}$ & 0.833 & 0.8474 & 0.666 & 0.666 & 0.588 & 0.55 & 1.282 & 1.562 & 0.833 \\
\hline
\end{tabular}

Table 6. Water test analysis for heavy metal on untreated sample.

\begin{tabular}{cccccccccc}
\hline Sample & $\mathrm{Fe}(\mathrm{ppm})$ & $\mathrm{Cr}(\mathrm{ppm})$ & $\mathrm{Pb}(\mathrm{ppm})$ & $\mathrm{Cu}(\mathrm{ppm})$ & $\mathrm{Mn}(\mathrm{ppm})$ & $\mathrm{Ni}(\mathrm{ppm})$ & $\mathrm{Cd}(\mathrm{ppm})$ & $\mathrm{Zn}(\mathrm{ppm})$ \\
\hline Result & 0.14 & 0.14 & 0.07 & 0.03 & 0.08 & 0.07 & $\mathrm{ND}$ & 0.06 \\
\hline
\end{tabular}

ND: not detected.

Table 7. Physiochemical test of treated samples.

\begin{tabular}{ccc}
\hline Physiochemical Parameter & Sample G & Sample H \\
\hline Total dissolve solid & $96 \mathrm{mg} / \mathrm{L}$ & $87 \mathrm{mg} / \mathrm{L}$ \\
Conductivity & $47 \mathrm{Ns} / \mathrm{cm}$ & $40 \mathrm{Ns} / \mathrm{cm}$ \\
PH & 6.6 & 6.9 \\
Hardness & $6.10 \mathrm{mg} / \mathrm{L}$ & $5.9 \mathrm{mg} / \mathrm{L}$ \\
Iron & $0.12 \mathrm{mg} / \mathrm{L}$ & $0.10 \mathrm{mg} / \mathrm{L}$ \\
Sulphate & $4.8 \mathrm{mg} / \mathrm{L}$ & $3.2 \mathrm{mg} / \mathrm{L}$ \\
Alkalinity & $96 \mathrm{mg} / \mathrm{L}$ & $98 \mathrm{mg} / \mathrm{L}$ \\
Turbidity & $1.4 \mathrm{NTU}$ & $1.2 \mathrm{NTU}$ \\
Chloride & $16.4 \mathrm{mg} / \mathrm{L}$ & $16.9 \mathrm{mg} / \mathrm{L}$ \\
Nitrate & $2.4 \mathrm{mg} / \mathrm{L}$ & $1.6 \mathrm{mg} / \mathrm{L}$ \\
Colour & Colourless & Colourless \\
Odour & Odourless & Odourless \\
Taste & Tasteless & Tasteless \\
\hline
\end{tabular}


Table 8. Analysis of sample G after treatment.

\begin{tabular}{ccccccccc}
\hline Sample & $\mathrm{Fe}(\mathrm{ppm})$ & $\mathrm{Cr}(\mathrm{ppm})$ & $\mathrm{Pb}(\mathrm{ppm})$ & $\mathrm{Cu}(\mathrm{ppm})$ & $\mathrm{Mn}(\mathrm{ppm})$ & $\mathrm{Ni}(\mathrm{ppm})$ & $\mathrm{Cd}(\mathrm{ppm})$ & $\mathrm{Zn}(\mathrm{ppm})$ \\
\hline Result & 0.04 & 0.12 & 0.04 & 0.03 & 0.04 & 0.01 & $\mathrm{ND}$ & 0.05 \\
\hline
\end{tabular}

ND: not detected.

Table 9. Analysis of sample $\mathrm{H}$ after treatment.

\begin{tabular}{ccccccccc} 
Sample & $\mathrm{Fe}(\mathrm{ppm})$ & $\mathrm{Cr}(\mathrm{ppm})$ & $\mathrm{Pb}(\mathrm{ppm})$ & $\mathrm{Cu}(\mathrm{ppm})$ & $\mathrm{Mn}(\mathrm{ppm})$ & $\mathrm{Ni}(\mathrm{ppm})$ & $\mathrm{Cd}(\mathrm{ppm})$ & $\mathrm{Zn}(\mathrm{ppm})$ \\
\hline Result & 0.04 & 0.06 & 0.03 & 0.01 & 0.03 & 0.03 & $\mathrm{ND}$ & 0.02 \\
\hline
\end{tabular}

ND: not detected.

\section{Conclusion}

From the obtained results within the limit of this research, it can be concluded that introduction of Glass-Snail shell ratio into a ceramic water filter composition can be effective for the removal of heavy metals and correction of physiochemical parameters in home use water.

\section{Recommendation}

For the treatment of water for home use sample $\mathrm{G}$ and $\mathrm{H}$ in Table 2 can be used to produce candle and pot types of ceramic water filter for the purification of water so as to prevent water borne diseases and cancers in our society.

\section{References}

Ajayi, B. A., Lamidi, Y. D., \& Owoeye, S. S. (2013). Possibility of Using Glass-Snail Shell for Industrial Waste Water Treatment. International Research Journal, 3, 8-11.

ASM International (1990). ASM Handbook Volume 01: Properties and Selection: Iron, Steel and High-Performance Alloys. Rusell Township, OH: ASM.

Bolton, M. (2009). "Rural Water Filter,” in Good Design—Energy Systems, Chicago.

Brown, J., Sobsey, M., \& Proum, S. (2007). WSP Field Notes, Improving Household Drinking Water Quality: Use of Ceramic Water Filters in Cambodia (pp. 1-44). Cambodia: WSP, UNICEF.

Coleman, N. J. (2011). 11 A Tobermorite Ion Exchanger from Recycled Container Glass. Internation Journal of Enviroment and Waste Managent,8, 366-382. http://dx.doi.org/10.1504/ijewm.2011.042642

Hagan, J., Harley, N., Pointin, D., Sampson, M., Vanna, S., \& Smith, K. (2009) Resource Development International. Cam bodia: Ceramic Water FIlter Handbook.

Katherine, L. C., \& Lauren, E. F. (2000). Implementation of an Appropriate House-Hold Water Purification System in Tourou, Cameroon. http://www.sys.virginia.edu

Kosek, M., Bern, C., \& Guerrant, R. L. (2003). The Global Burden of Diarrhoeal Disease, as Estimated from Studies Published between 1992 and 2000. Bull World Health Organ, 81, 197-204.

Lantagne, D. S. (2001). Investigation of the Potters for Peace Colloidal Silver Impregnated Ceramic Filter: Report2: Field Investigations (April 6, 2010). Boston: Alethia Environment.

Onda, K., LoBuglio, J., \& Bartram, J. (2012). Global Access to Safe Water: Accounting for Water Quality and the Resulting Impact on MDG Progress. International Journal of Environmental Research and Public Health, 9, 880-894. http://dx.doi.org/10.3390/ijerph9030880

Potter for Peace (2006). A Complete Guide to Ceramic Filter at RDIC (Research Development International Cambodia). Cambodia: Potter for Peace. www.potterforpeace.org

Prajapati, H. G. (2002). Madhyapur Clay Crafts. In J. Low (Ed.)

Sobsey, M. D., Stauber, C. E., Casanova, L. M., Brown, J. M., \& Elliott, M. A. (2008). Point of Use Household Drinking Water Filtration: A Practical, Effective Solution for Providing Sustained Access to Safe Drinking Water in the Developing World. Environmental Science and Technology, 42, 4261-4267. http://dx.doi.org/10.1021/es702746n 
Water Exchange (2012). History of Water Filters.

http://www.thewaterexechange.net/history-of-water-filters-from-ancient-to-present.htm

WHO/UNICEF (2010). Meeting the MDG Drinking Water and Sanitation Target: A Mid-Term Assessment of Progress. Geneva and New York: World Health Organization and UNICEF. 